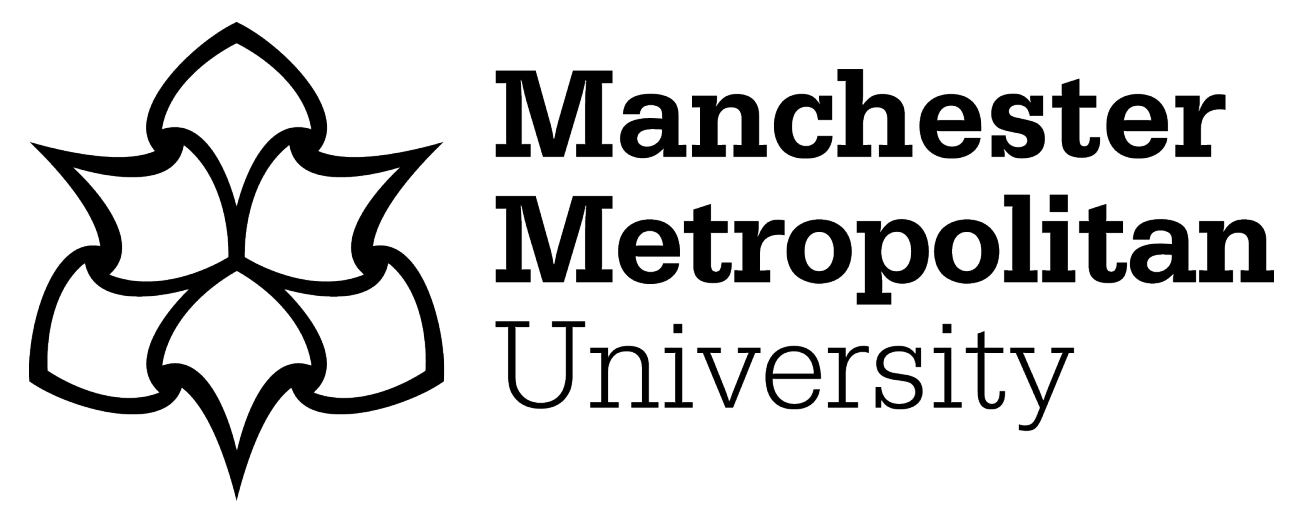

Ashbee, Edward and Hurst, Steven (2020) The Trump foreign policy record and the concept of transformational change. Global Affairs, 6 (1). pp. 5-19. ISSN 2334-0460

Downloaded from: https://e-space.mmu.ac.uk/626291/

Version: Accepted Version

Publisher: Informa UK Limited

DOI: https://doi.org/10.1080/23340460.2020.1734954

Please cite the published version 


\title{
The Trump Foreign Policy Record and the Concept of Transformational Change
}

\begin{abstract}
While there has been debate about the extent to which US foreign policy has been transformed since President Trump first took office in 2017, the concept of transformational policy change has not been defined with any degree of precision. The purpose of this article is, primarily, to establish such a definition. It does this by drawing upon a number of the literatures that address domestic policy processes, in particular the work of Karl Polanyi, to suggest that transformational change rests upon paradigmatic shifts, the reconfiguration of interests, large scale institutional re-ordering and changed logics. Application of the definition to the Trump foreign policy leads us to conclude that while the Trump foreign policy owes much to the militant internationalism of the Bush years its understanding of nations and "globalism" and abandonment of a defining moral purpose represent, although incipient, partial and variegated, the beginnings of transformational change.
\end{abstract}

\section{Introduction}

As the introduction to this special issue demonstrated, arguments about whether the Trump presidency has seen a dramatic transformation of US foreign policy are fierce and ongoing. Largely absent from the debate, however, is the question of what constitutes transformational 
foreign policy change. Yet without an answer to that question the debate will remain unresolved. In the absence of clear criteria, even consensus as to the facts may not lead to agreement regarding the degree of change. What constitutes minor change in one conceptual schema may be classified as transformational under another (Bauer and Knill, 2014, p. 29). ${ }^{1}$

Our objective in this paper is therefore to consider the character of transformational foreign policy change. We focus on transformational change not only because of the debate surrounding the Trump foreign policy but also because, while all presidents can enact some degree of change, what is of real significance is the distinction between policy transformations and lesser order shifts.

An initial survey of the literature on foreign policy change reveals a focus on explanations of change rather than on definitions of change. Moreover, what attention has been devoted to the latter problem has produced little in terms of conceptual schema. We therefore look towards the literature in historical institutionalism, presidential scholarship and economic history in order to offer a model that rests upon processes of ideational change, the development of new or reconfigured coalitional blocs, institutional changes and the creation of different logics. In the subsequent section of the paper we demonstrate the utility of the model in a foreign policy context by applying the concepts developed to the post-1945 transformation of US foreign policy. Finally, we provide an indicative sketch applying the model to the Trump administration's foreign policy. We do not seek, in doing so, to draw definitive conclusions or offer a comprehensive survey. Rather, we demonstrate how the model provides a basis for a systematic approach to assessing change.

\section{Foreign Policy Analysis and Definitions of Change}


As Kleistra and Mayer (2001, p. 387) observed, the Foreign Policy Analysis (FPA) literature addressing change is "strong on detailing the independent variables" but pays "little attention to the dependent variable. What changes? To what extent?". A survey reveals explanatory models that focus on policy entrepreneurs and policy windows (Blavoukos \& Bourantonis, 2014), problems of structure and agency (Carlsnaes, 1993) and facilitators of and obstacles to change (Goldmann, 1988; Kleistra \& Meyer, 2001). In addition, there are studies that examine role theory (Grossman, 2005), decision-making processes (Kuperman, 2006), domestic politics (Doeser, 2011) and policy sequencing (Ozkececi-Tanner, 2006). Other analyses emphasize the role of ideas (Risse-Kappen, 1994; Widmaier et al, 2007) culture (Rynhold, 2007) and policy failure (Walsh, 2006; Welch, 2005). Finally, there have been attempts to develop multi-causal models of change (Gustavsson 1999; Herrmann, 1990; Holsti, 1982; Holsti et al 1980; Rosati et al 1994). With few exceptions, the question of how to define and measure change is given limited attention in these analyses.

Nevertheless, a handful of scholars have sought to address those questions. Holsti (1982, p. 2) defines foreign policy "restructuring" as "a type of foreign policy behaviour where governments seek to change, usually simultaneously, the total pattern of their external relations". Rosati (1994, p. 236) also employs the term "restructuring" to refer to the highest level of change in a four-fold typology, defining it as involving "major changes in scope, goals and strategy". Hermann (1990, p. 5) uses a four-fold typology with "international reorientation" at the top, which he defines as a "redirection of the actor's entire orientation toward world affairs .... Not one policy but many are more or less simultaneously shifted". Finally, Volgy \& Schwarz (1994, pp. 25-6) define foreign policy restructuring as a "comprehensive change in the foreign policy orientation of a nation, involving multidimensional change in behaviour which is rapid rather than incremental". Despite 
acknowledging the need to differentiate between varying degrees of change, however, these scholars fail to develop their definitions beyond these broad summary statements. To distinguish between foreign policy "restructuring" and foreign policy "reform" by stating that the former involves "major changes in scope, goals and strategy" and the latter only "moderate" changes (Rosati, 1994, p. 236) offers scant guidance as to how these concepts might be operationalized in practice. Hence there is a need for a more precise definition of transformational foreign policy change.

\section{Depicting and Defining Transformational Change}

Although neglected in FPA, there have been efforts to disaggregate and define the concept of transformational change in other literatures. These include some work in economic and social history and studies of American political development (APD). Many of these accounts draw implicitly and at times openly upon the thinking of Karl Polanyi and his widely cited book The Great Transformation (1944/2001). Taking the literature collectively, the concept of transformational change rests upon a series of structural shifts that generally take place amidst flux or in the wake of crises.

These shifts included, first, paradigmatic change. A paradigm is understood as 'a framework of ideas and standards that specifies not only the goals of policy and the kind of instruments that can be used to attain them, but also the very nature of the problems they are meant to be addressing' (Hall, 1993, p. 279). Paradigmatic changes rest upon shifts in the character of both background ideas (which are taken-for-granted assumptions) and foreground ideas (which take a more open and explicit form) as well as both cognitive and normative thinking. Cognitive ideas identify causes and their effects whereas normative ideas rest upon values, principles and preferences (Campbell, 2004, p. 93). The extent to which change can be deemed transformational is in part a function of the degree to which new ideas become a 
form of "common sense". Thus, as Keynesianism was displaced during the 1970s and early 1980s there was a wholesale change in the system of economic ideas which "specified what the economic world was like, how it was to be observed, which goals were attainable through policy, and what instruments should be used to attain them" (Hall, 1993, p. 279).

Second, transformational change involves "fundamental shifts in power and representation of interests and values" (Pelling, 2011, p. 84). It entails the rise of new interests and the formation of different coalitions between interests. In his studies of the US presidency, Stephen Skowronek ties transformational shifts to the reconfiguration of interests alongside ideational change: Thus:

\begin{abstract}
American government and politics are transformed when new interests secure a firm grip on power, when institutional relationships are rearranged to support them, when government priorities are durably recast, and when a corresponding set of legitimating ideas becomes the new common sense (Skowronek: 2011, p. 171).
\end{abstract}

The New Deal era illustrates the ways in which interests are reconfigured in a transformational period, with the new-found dominance of the Democratic Party based on increasingly powerful unions and the ascendancy of a different "investor bloc" or corporate coalition based upon the investment banks and the capital-intensive industries that looked towards international markets and were less "labor-sensitive" than more traditional laborintensive firms (Ferguson, 1995, pp. 121-129). ${ }^{2}$

Third, the concept of transformational change encompasses shifts in the character of both formal and informal institutional structures insofar as they have an implementational role or 
adapt in response to shifting systems of ideas. If, for example, the course of US history during the latter half of the twentieth century is considered on a long-run basis, and notwithstanding the recent efforts of the right to rein in collective social provision, shifting ideas about the role of government, the responsibilities it should undertake, and the rights of the citizen, led to a dramatic shift in the locus of governmental authority from the individual states to Washington DC (Pierson and Skocpol, 2007, p. 4).

Fourth, the shifts in ideas, institutions and interests lay the basis for the final defining feature of transformational change -they redirect logics. The concept of a "logic" takes different forms but can be understood as "a set of goals or motivations that influence the way in which actors organize their preferences" (Etienne and Schnyder, 2014, p. 367). This, in turn, lays a basis for particular choices, actions and events. In sum, logics provide an institutional and ideational architecture shaping political behaviour. Shifts in logics may occur through "critical junctures" - those relatively short periods during which one policy trajectory is adopted rather than another - or take place through more incremental change processes.

Changes in logics set off new "chains of temporally ordered and causally connected events ... each event within the sequence is in part a reaction to temporally antecedent events" (Mahoney, 2000, p. 509). These sequences then create a succession of opportunity structures that lay a basis and set a framework that incentivizes or disincentivizes particular forms of behaviour. Transformational change thus represents a radical shift in logics, (which may be either intentional or the function of a contingent event), a repudiation of the past and the triggering of different sequences. . For Polanyi, the logic of the market created "an unparalleled momentum" (Polanyi, 2001, orig. 1944, p. 80). Similarly, the paradigmatic, coalitional and institutional changes associated with the New Deal set in train logics and 
sequences structured around an enlarged role for government and a partial amelioration of untrammeled capitalism that persisted over decades.

The literature considering transformational change within domestic arenas has a further relevance for the study of major shifts in the direction of foreign policy. As noted above, where studies within FPA have addressed the character of change processes, they have often assumed that to be transformational, change must take place across a broad range of policy areas at the same time. Nonetheless, as studies of American political development have stressed, different policy regimes have their own origins and history and each therefore has its own tempo and pace (Lieberman, 2002, p. 701). As a consequence, and although there will be periodic compatibilities or "fits" between policy regimes, there will just as probably be incongruity and irresolution (Orren and Skowronek, 2004, p. 17). Seen in this way, it is very unlikely that transformational change will take place evenly or across multiple policy regimes at the same time. Instead, such change will be uneven and variegated. If an observer were to insist that it must by definition rest upon simultaneous shifts across many policy regimes transformational change could never be found.

\section{Transformational Change in a Foreign Policy Context}

Perhaps the most widely acknowledged example of transformation in recent US foreign policy occurred during the 1940s, when the US embraced Liberal Internationalism (LI) ( Ikenberry 2001; 2011, pp. 159-220; Ruggie, 1996). That episode serves as a valuable test of the model outlined above and one where the passage of time allows us to demonstrate its utility more definitively. 
In the first instance, there is little question that the adoption of LI rested upon a paradigmatic shift. In adopting LI the US committed itself to open-ended international engagement and global leadership - a decisive break with the far more limited forms of international engagement that characterized pre-war US foreign policy deriving from a fundamental reconceoptualization of America's global role (Ikenberry, 2011, pp. 159-219; Ruggie, 1996). ${ }^{3}$ Moreover, that shift was tied to a reconfiguration of social, economic and regional interests. Historically protectionist northern industries, newly globally competitive, turned toward free trade and a foreign policy that would ensure access to foreign markets while the south, dependent upon the export of cotton and agricultural products, continued to back free trade. LI was also supported by the eastern wing of the Republican Party because of its financial interests while fear of Soviet expansionism reinforced the commitment of all three groupings to the new paradigm (Trubowitz, 1998, pp. 96-168). In consequence, the nationalist / isolationist Mid-Western wing of the Republican Party, representing those interests opposed to LI was politically marginalized (Miles, 1980, pp. 82-92; Kupchan and Trubowitz, 2007, pp. 11-15).

The adoption of LI was also associated with far-reaching institutional transformation. Washington led the construction of the United Nations, the International Monetary Fund, the World Bank and the General Agreement on Tariffs and Trade while also committing itself to NATO and the US-Japan Security Treaty. Internally, the adoption of LI led to the creation of a national security state with the capacity to implement America's new global role. The National Security Act of 1947 merged the existing military departments into a single Department of Defense and created the Joint Chiefs of Staff, the National Security Council and the CIA (Stevenson, 2008). 
Finally, the adoption of LI set in place logics that were sustained over a long period. The institutional infrastructure erected in the 1940s was subsequently expanded and the commitment to the LI paradigm amongst US policy-makers became a firmly established article of faith (Goldstein, 1988; Porter, 2018). Support for the core features of LI, including continued international engagement, multilateralism, free trade and the principal US alliances, remained strong across both main principal political parties for decades (Chaudoin, Miller and Tingley, 2010; Page and Shapiro, 1992). The transformational change processes that characterized liberal internationalism are summarized in Table 01.

[Table 1 here]

\section{Trump and Transformation}

John Ikenberry has claimed that, with Trump's election, "for the first time since the 1930s, the United States has elected a president who is actively hostile to liberal internationalism" (Ikenberry, 2018, p. 7). Yet in reality, many on the American right rejected core tenets of LI before Trump became president. In order to determine whether or not Trump's foreign policy represents a paradigmatic shift, therefore, we need to establish what remained of LI by 2016.

From the 1970s onwards elite US foreign policy opinion has become more fragmented.

Different frames have been used to try and conceptualize the result (Holsti and Rosenau, 1990) wherein new groupings, which retained some elements of the LI paradigm but abandoned others, have emerged. The key developments in this context were the rejection of LI by two groupings moving in opposite directions. While some former liberal internationalists (mainly Democrats) increasingly rejected the use of force as a tool of foreign policy another grouping, (mainly Republicans) came to reject the cooperative dimensions of LI While still internationalist in character, this latter worldview, which we refer to here as 
militant/conservative internationalism, ${ }^{4}$ rejected the cooperative elements of LI such as foreign aid, treaties and, in particular, multilateral institutions such as the United Nations, which were deemed to impede America's pursuit of its national interest. For this grouping "hard" power remained the decisive instrument of foreign policy and was most effectively used unilaterally or in ad hoc coalitions rather than under multilateral constraints (Holsti and Rosenau, 1990; Maggiotto and Wittkopf, 1981 Nincic and Datta, 2007).

Nevertheless, militant/conservative internationalism retained some elements from the LI paradigm. In particular, there was a continued faith in democracy and freedom, which were seen as important guarantors of peace. George W. Bush's decision to invade Iraq demonstrated this belief operating in conjunction with the characteristic disdain for multilateralism. Moreover, although there were aberrations, militant/conservative internationalists also demonstrated a continued commitment to trade liberalization. George W. Bush sought to reinvigorate the Doha round of multilateral trade negotiations at the World Trade Organization (WTO) and committed his administration to a range of regional and bilateral free trade initiatives such as the Middle East Free Trade Area (MEFTA), the Free Trade Area of the Americas (FTAA) and the Central America Free Trade Area (CAFTA) (Chorev, 2009).

While there are certainly some continuities with the militant / conservative internationalist paradigm that has dominated recent Republican foreign policies (unilateralism, increases in military spending), Trump's foreign policy nevertheless represents a break with that paradigm. In its place Trump offers a populist and nationalist worldview structured around five distinct propositions that interweave cognitive and normative ideas (Wojczewski, 2019). 
The first of these is that the nation, understood as being structured around a distinct ethnicity rather than ideals or principles, is core. Steve Bannon, the White House Chief Strategist between January and August 2017 and a key influence on Trump, declared that "the center core of what we believe, [is] that we're a nation with an economy, not an economy just in some global marketplace with open borders, but we are a nation with a culture - and a reason for being" (Beckwith, 2017).

Second, from a nationalist perspective, nations are necessarily engaged in intense competition with each other in a struggle for hegemony and there are therefore profound limits to international cooperation and partnership. The US National Security Strategy published at the end of 2017 used the term "competition" eighteen times (The White House, 2017) and such competition is seen in zero-sum terms and as a process from which the US has recently been losing. As Trump expressed it in his inaugural address, "we've made other countries rich, while the wealth, strength and confidence of our country has dissipated over the horizon" (Trump, 2017).

Third, in all its different guises, the merging of populism and nationalism rests upon a sense that the particular nation to which it is tied, and its people, have suffered because of "globalism" and the global elites that Bannon once dubbed "the party of Davos". For Trump, "you know what a globalist is, right? .... A globalist is a person that wants the globe to do well, frankly not caring about our country so much." (Forgey, 2018). A Trump campaign advertisement lambasted the "global power structure responsible for the economic decisions that have robbed our working class, stripped our country of its wealth, and put that money into the pockets of a handful of large corporations and political entities" (C-Span, 2016). 
It flows from this that, in contrast to globalizing assumptions, markets and trade flows should be subordinated to the nation and national purposes. They have to be tamed, structured and regulated: "the economy should be bent and shaped to serve the nation and its 'reason for being"' (Bannon, quoted in Garver, 2017). Multilateral trade deals are deemed to dissipate American leverage, hence Trump's hostility toward NAFTA and the TPP, whereas 'one-onone deals will almost always favour America, given its sheer preponderance' (Stokes, 2018, p. 137), Consequently, in Trump's own words, "believe me, we're going to have a lot of trade deals. But they'll be one-on-one. There won't be a whole big mash pot" (Gertz, 2017). This is a worldview that rejects the commitment to multilateral trade liberalization common to all preceding forms of post-war internationalism.

Finally, the sense of moral vision that informed both liberal internationalism and the militant, conservative internationalism embraced by much of the Republican Party from the 1980s onwards has been largely abandoned. Ronald Reagan invoked the "shining city" while George W Bush boasted that "a liberated Iraq has showed the power of freedom to transform the Middle East by bringing hope and progress to the lives of millions" (CNN.com, 2005). Trump, in contrast, not only turned away from regime change as an instrument for the promotion of democracy but eschewed such visions. Even claims that the US could win across others to its founding principles by dint of example were reined in. He announced that "we are not here to lecture - we are not here to tell other people how to live, what to do, who to be, or how to worship" (Phillip and Nakamura, 2017).

To what extent, if any, has this populist nationalist paradigm become a new "common sense"? On the one hand, it has resonated powerfully with a significant portion of the 
American electorate. As Gary Jacobson noted in the aftermath of the 2016 elections: "Trump connected with the substantial minority of Americans who feel besieged economically and culturally by globalism, the growing racial and ethnic diversity of the American population, and changing cultural norms" (Jacobson, 2017, p. 21). And Trump has consolidated that support during his presidency. His approval ratings amongst the Republican base have remained consistently in the high 80s (Gallup, 2019) while polls also demonstrate that a significantly larger proportion of the Republican electorate consider themselves to be "more of a supporter of Donald Trump" than they are of the Republican Party itself ( $N B C /$ Wall Street Journal, 2018). On the other hand Trump is a uniquely polarizing figure, even by the standard of contemporary US politics. The same polls that indicate consistently high levels of Republican support for Trump show approval of Trump amongst Democrats consistently in single figures (Gallup, 2019). It is unclear, therefore, how Trump's populist paradigm can extend its grip beyond his current supporters. ${ }^{5}$

Alongside these ideational shifts, there has been a limited but discernible reconfiguration of interests under Trump. There was some displacement of the foreign policy "establishment" and significant strains between the administration and peak business organizations such as the US Chamber of Commerce over trade policy (Mullins \& Leary, 2019, p. A9). Factions within the administration, represented most prominently by Steve Mnuchin, who were most closely tied to finance and business, were frequently overshadowed by the "trade hawks".

Potentially most significant, however, is the reconfiguration of the Republican party's "base". The success of Trump's populist message precipitated an acceleration of the decline in the Democratic Party's hold on the white working-class (Tyson \& Maniam, 2016). Estimates suggest that about 8.4 million voters who backed Obama in 2012 supported Trump four years 
later (Skelley, 2017). The crucial importance of this demographic group to Trump's victory, allied to other changes in the demographics and voting behaviour of the electorate, means that "for Republicans, future [electoral] success is tied to mobilizing their strength among whites without college educations" (Griffin, Teixeira \& Frey, 2018, p. 4). This has significant policy implications. A study of the Republican primary electorate found that Trump voters were not only more critical of immigration and free trade but also disproportionately believed that the US "does too much to solve world problems" and the country's involvement in the world economy was a "bad thing" (Smith, 2016).

To what extent has the Trump presidency initiated a process of institutional change? While Trump has withdrawn the United States from the Joint Comprehensive Plan of Action (JCPOA) with Iran and the INF Treaty, the overall pattern in relation to the international security architecture has largely been one of continuity. The alliance relationships that Trump inherited remain intact. ${ }^{6}$ When it comes to the non-security related institutional architecture, in contrast, we find "remarkable discontinuity" (Stokes, 2018, p. 137). Trump has pulled the US out of a series of agreements and commitments including the Paris Agreements on climate change, the Trans-Pacific Partnership (TPP), the UN Human Rights Council and UNESCO. He has also sought to undermine the primary institutional guardian of multilateral trade, the World Trade Organization (WTO), by refusing to allow the appointment of judges to fill vacancies on the WTO's Appellate Body, thereby limiting its capacity to adjudicate trade disputes (Brinkley, 2018).

Trump has taken a similar approach to parts of the foreign policy bureaucracy in Washington DC, with the Department of State (DOS) bearing the brunt. Trump's first Secretary of State, Rex Tillerson, implemented a budget cut of one-third, cancelled the incoming intake of 
foreign service officers and oversaw the departure of sixty percent of the Department's most senior diplomats in his first year in office (Bergmann, 2017; Corrigan, 2018) Nancy McEldowney, one of the senior diplomats who left in Trump's first year, said of the new administration, "in the anatomy of a hostile takeover and occupation, there are textbook elements-you decapitate the leadership, you compartmentalize the power centers, you engender fear and suspicion. They did all those things" (quoted in Osnos, 2018). The cumulative effect of these actions has been to "systematically accelerate[d] the decline of the State Department's capacity to perform its traditional role representing the United States to foreign nations" (Pfiffner, 2018, p. 161).

The intelligence community (IC) has been the next most prominent target, with Trump ignoring or belittling the IC when it has failed to produce intelligence that conforms to his own prejudices. When the IC's 2019 Worldwide Threat Assessment drew conclusions about North Korea, Iran and climate change at odds with his own, Trump responded by declaring that the "Intelligence people" were "passive and naive" and that "perhaps they should go back to school!" (Rohde, 2019). This open criticism of the IC, combined with the actions taken against FBI Director James Comey and former CIA Director John Brennan, suggest that Trump is engaged in a systematic and "deliberate effort to diminish the IC's institutional credibility" (Sipher \& Haas, 2019; see also Slick, 2018).

For its part the Department of Defense (DOD), while not deprived of funding in the same way as the DOS, has been deprived of effective leadership and institutional influence in a not dissimilar fashion, if not to the same extent. In the spring of 2019 the Secretary and Deputy Secretary of Defense were both acting in their roles. Two of seven Under-Secretaries were 
also acting or temporary as were nearly half of all the Assistant Secretaries, while many Deputy-Assistant Secretary positions remained unfilled (Seligman \& Gramer, 2019).

The overall effect of this systematic effort to weaken and bypass the national security bureaucracy has been to undermine the normal interagency process and centralise decisionmaking in the White House. As former French Ambassador to the USA Gerard Araud put it, "we don't have interlocutors.... when we have people to talk to they are acting, so they don't have real authority. The consequence is that there is one centre of power: The White House". (Borger, 2019).

Although policy in east Asia may prove to be an exception, the logics created or given added momentum elsewhere during the Trump years loosened the US's commitment to the liberal international order and the architecture of post-war security arrangements. Although the United States' primary security relationships remain intact, the instability that characterized the administration's policymaking processes, the doubts about the security guarantees upon which NATO and other alliances are premised and the demands for increased spending, have compelled allies to think more in terms of self-reliance or about the construction of a security architecture that is less reliant upon US military capacity. This will be a slow and uneven process, given the fiscal constraints upon alliance countries, but might be hastened by an understanding that the deterioration of relations with China could lead the US to shift more of its military capacity towards the Asian theatre.

There are some signs of momentum. Questions about NATO added to an increasingly vocal scepticism in some Washington DC policy thinktanks about the US's security guarantees and intensified fears that the US could be drawn into a major war as a result of a very small incident because it had over-promised allies that it would invariably come to their aid with 
military might. This led to the argument that the US should reassess the character of its security assurances and explore non-military forms of action such as sanctions (O'Hanlon, 2019). ${ }^{7}$

Furthermore, although this had been set in motion before Trump took office, the administration's retreat from trade liberalization and multilateral trading arrangements appears to mean that future free trade agreements will be subject to much greater domestic scrutiny and changed political cost-ratios. Even if they do not subscribe to Trump's neomercantilist claims, it will be difficult for those who succeed him to re-embrace unfettered trading relationships. At the same time, the US's retreat from trade liberalization appears to have provided an impetus for forms of trans-national economic connectivity that do not include the US. Following the US's withdrawal from the Trans-Pacific Partnership at the beginning of 2017, Japan and other nations agreed to revive the agreement and in March 2018, signed a revised version of the agreement.

The transformational change processes that characterized the Trump administration during its first two years are summarized in Table 02 .

[Table 2 here]

\section{Conclusion}

By developing a conceptual framework, we have established a basis for evaluating foreign policy change. It sets a high bar for deciding upon the forms of change that are to be regarded as "transformational" but this is deliberate. The term is often used haphazardly or simply to refer to processes of change across different spheres. We assert that the concept should be used with greater precision so as differentiate policy changes that are truly transformational 
from those that may be dramatic in character but do not bring about enduring shifts in ideas, interests, institutions and logics.

Having said this, the scale of shifts that are set in train may well not be fully evident at the point in time when reform processes are initiated. This is because reforms are for the most part introduced incrementally and their effects often do not become clear for decades. It is noteworthy that many of the most widely-cited studies of change during the Reagan era were only published some years later. Nonetheless, the framework developed in this article puts us in a stronger position to attempt a "first cut" at assessing the extent to which the Trump presidency has transformed US foreign policy.

In applying the framework, we find a mixed picture. Some of the most dramatic changes have been ideational. Despite some continuities and overlaps with militant/conservative internationalism, the populist paradigm represents an important shift in the bases of foreign policy thinking. Institutional reconfigurations are characteristically slower but even here, during the first three years of the Trump presidency, there was significant change. Shifts in societal and economic interests were also evident as established peak business interests were largely sidelined. The acceleration of the change in voting allegiances, and the likelihood that the future electoral success of the Republican Party will be dependent on maintaining the loyalty of the non-college educated white voters should also be emphasized. Hardest of all to identify at this early juncture are logics of action, but there is evidence that some changed logics were set in motion, most obviously in trade policy, and there were some indications that the terms of debate about US security guarantees were changing whilst other countries appeared to begin seeking to foster relationships that depended less upon US leadership. 
Nonetheless, some caveats should be introduced. First, the degree to which there has been paradigmatic change beyond the ranks of the Trump "base" is uncertain. There is polling evidence of continuing popular support for some forms of internationalism although there continues however to be a sharp distinction between high levels of support for NATO and far lower levels of backing for the United Nations (Brands, 2018: 87 - 88; Tarrance, 2019). Furthermore, although the divide opened up before Trump's ascendancy, there are now unprecedented partisan gaps between Democratic and Republican identifiers when it comes to issues such as democracy promotion and support for human rights overseas and the provision of assistance for developing countries (Pew Research Center, 2018).

Moreover, populism is by definition a "thin" ideology (Mudde, 2004: 544). As such, it forms an ideational crust on top of other ideologies. There is therefore a possibility that the Trump administration will be pulled away from populism and back towards the conservative or militant internationalism than defined George W Bush's years in office.

Similarly, the extent and scale of the institutional shifts that have taken place should not be exaggerated. For all Trump's questioning of them, the US remains locked into the key institutional security arrangements that were established during the post-war era and consolidated in subsequent decades. Domestically, while Trump has effectively marginalized much of the national security bureaucracy he has not engaged in the kind of reconstruction or reconfiguration of it which would create a self-sustaining institutional basis for the populist nationalist paradigm (Drezner, 2019). There has been a further shift among white working class voters towards the Republicans but it may not last and the changes in logics initiated thus far are limited in character and, in most cases, tentative. In sum, there are the beginnings of transformational change but it is incipient, partial and variegated. 


\section{References}

Bauer, M. W. and Knill, C. (2014). A conceptual framework for the comparative analysis of policy change: Measurement, explanation and strategies of policy dismantling. Journal of Comparative Policy Analysis: Research and Practice, 16 (1), 28-44.

Bergmann, M. (2017). Present at the destruction: How Rex Tillerson is wrecking the State Department. Politico.com 29 June. Retrieved from https://www.politico.com/magazine/story/2017/06/29/how-rex-tillerson-destroying-statedepartment-215319.

Blavoukos, S. and Bourantonis, D. (2014). Identifying parameters of foreign policy change: An eclectic approach. Cooperation and Conflict. 49 (4), 483-500.

Borger, J. (2019, April 21). France's ambassador to US bows out aghast at court of 'Sun King' Trump. The Observer.

Brands, H. (2018). American Grand Strategy in the Age of Trump. Washington DC: Brookings Institution Press.

Brinkley, J. (2018, September 27). Trump is close to shutting down the WTO's appeal court Forbes. Retrieved from: https://www.forbes.com/sites/johnbrinkley/2018/09/27/trump-isclose-to-shutting-down-the-wtos-appeals-court/\#432ff07ab6b4.

Bush, G.W. (2003, November 9). President Bush discusses Iraq policy at Whitehall Palace in London. Retrieved from: https://georgewbushwhitehouse.archives.gov/news/releases/2003/11/20031119-1.html. 
Campbell, J.L. (2004). Institutional Change and Globalization. Princeton: Princeton University Press.

Carlsnaes, W. (1993). On analysing the dynamics of foreign policy change: A critique and reconceptualization. Cooperation and Conflict 28 (1), 5-30

Chaudoin S, Milner, H.V. and Tingley, D.H. (2010). The center still holds: Liberal internationalism survives. International Security 35 (1), 75-94.

Chorev, N. (2009). International trade policy under George W Bush in A. Wroe \& J. Herbert (eds) Assessing the George W. Bush Presidency: A Tale of Two Terms (pp. 129-48).

Edinburgh: Edinburgh University Press.

Corrigan. J, (2018, February 11). The Hollowing out of the State Department continues. The Atlantic.com. Retrieved from:

https://www.theatlantic.com/international/archive/2018/02/tillerson-trump-state-foreignservice/553034/.

C-Span, (2016. November 4). Trump Presidential Campaign Ad. Retrieved from: https:/www.c-span.org/video/?418167-101/trump-presidential-campaign-ad.

Daalder, I.H. \& Lindsay, J.M. (2003). America Unbound: The Bush Revolution in Foreign Policy. New York: Wiley. 
Doeser, F. (2011). Domestic politics and foreign policy change in small states. The fall of the Danish 'footnote policy'. Cooperation and Conflict 46 (2), 222-241.

Dollar, D., Hass, R. \& Bader, J.A. (2019, January 15). Assessing U.S. - China relations 2 years into the Trump presidency. Retrieved from: https://www.brookings.edu/blog/order-fromchaos/2019/01/15/assessing-u-s-china-relations-2-years-into-the-trumppresidency/?utm_campaign=John\%20L.\%20Thornton $\% 20$ China $\% 20$ Center\&utm_source=hs _email\&utm_medium=email\&utm_content $=69452634$

Domhoff, G.W. (1990). The Power Elite and the State: How Policy is Made in America. New Jersey: Aldine De Gruyter.

Drezner, D. (2019). Present at the destruction: The Trump administration and the foreign policy bureaucracy. The Journal of Politics 81 (2), 723-30.

Edmondson, C. (2019, January 31). Senate rebukes Trump over troop withdrawals from Syria and Afghanistan. The New York Times. Retrieved from: https://www.nytimes.com/2019/01/31/us/politics/senate-vote-syria-afghanistan.html Etienne, J. and Schnyder, G. (2014). Logics of action and models of capitalism: explaining bottom-up non-liberal change. Swiss Political Science Review, 20 (3), 365 - 387.

Ferguson. T. (1995). Golden Rule: The Investment Theory of Party Competition and the Logic of Money-Driven Political System, Chicago: The University of Chicago Press.

Forgey, Q. (2018, October 22). Trump: 'I'm a nationalist'. Politico.com. Retrieved from: https://www.politico.com/story/2018/10/22/trump-nationalist-926745. 
Gaddis, J.L. (2004). Surprise, Security and the American Experience. Harvard: Harvard University Press.

Gallup, (2019). Presidential approval ratings: Donald Trump. Retrieved from: https://news.gallup.com/poll/203198/presidential-approval-ratings-donald-trump.aspx

Galvin, D J. (2012). The transformation of political institutions: Investments in institutional resources and gradual change in the national party committees. Studies in American Political Development, 26 (1), 1-21

George, A.L. (1980). Domestic constraints on regime change in US foreign policy: The need for political legitimacy. In O.R. Holsti, R.M. Siverson \& A.L. George (eds) Change in the International System (pp. 233-62). Boulder: Westview.

Gertz, G. (2017, February 8). What will Trump's embrace of bilateralism mean for America's trade partners? Retrieved from: https://www.brookings.edu/blog/futuredevelopment/2017/02/08/what-will-trumps-embrace-of-bilateralism-mean-for-americastrade-partners/.

Goldmann, K. (1988). Change and Stability in Foreign Policy. Princeton: Princeton University Press.

Goldstein, J. (1988). Ideas, institutions, and American trade policy, International Organization, 42 (1), 179-217. 
Griffin, R. Teixeira, R. \& Frey, W.H. (2018). America's electoral future: Demographic shifts and the future of the Trump coalition. Bipartisan Policy Centre. Retrieved from: https://bipartisanpolicy.org/wp-content/uploads/2018/04/States-of-Change-AmericasElectoral-Future.pdf

Grossmann, M. (2005). Role theory and foreign policy change. International Politics, 42 (3), $334-51$.

Gustavsson, J. (1999). How should we study foreign policy change? Cooperation and Conflict 34 (1), 73-85.

Hall, P. A. (1993). Policy paradigms, social learning, and the state: The case of economic policymaking in Britain. Comparative Politics, 25 (3), 275-296

Halper, S. and Clarke, J. (2004). America Alone: The Neo-Conservatives and the Global Order. Cambridge: Cambridge University Press.

Herrmann, C.F. (1990). Changing course: When governments choose to redirect foreign policy. International Studies Quarterly, 34 (1), 3-21.

Holsti, K.J. (1982). Why Nations Realign: Foreign Policy Restructuring in the Postwar World. London: Routledge.

Holsti, O.R, Siverson, R.M. and George, A.L. (eds) (1980). Change in the International System. Boulder: Westview. 
Holsti, O. R. and J. N. Rosenau (1990). The structure of foreign policy attitudes among American leaders. The Journal of Politics, 52 (1), 94-125.

Hurst, S. (2009). Is the Bush Revolution over? International Politics, 46 (2/3), 157-76.

Ikenberry, G.J. (2001). After Victory: Institutions, Strategic Restraint, and Rebuilding of Order after Major Wars. Princeton NJ: Princeton University Press.

Ikenberry, G.J. (2002). America's imperial ambition. Foreign Affairs, 81 (5), 44-60.

Ikenberry, G.J. (2011). Liberal Leviathan: The Origin, Crisis and Transformation of the American World Order. Princeton: Princeton University Press.

Ikenberry, G.J. (2018). The end of liberal international order? International Affairs, 94 (1), 7 23.

Jacobson, Gary C. (2017). The triumph of polarized partisanship in 2016: Donald Trump's improbable victory', Political Studies Quarterly, 132 (1), 9-41.

Jervis, R. (2003). Understanding the Bush Doctrine. Political Science Quarterly, 118 (3), $365-388$.

Johnson, J. (2020, January 21). In similar move to Japan, South Korea to deploy anti-piracy unit to Middle East amid U.S. pressure. The Japan Times. Retrieved from https://www.japantimes.co.jp/news/2020/01/21/asia-pacific/japan-south-korea-military$\underline{\text { middle-east-us-iran-patrol/\#.XjXtGxoo mo }}$ 
Kleistra, Y. and Mayer, I. (2001). Stability and flux in foreign affairs: Modelling policy and organizational change. Cooperation and Conflict, 36 (4), 381-414.

Kupchan, C.A. and Trubowitz, P.L. (2007). Dead center: The demise of Liberal Internationalism in the United States. International Security, 32 (2), 7-44.

Kuperman, R.D. (2006). A dynamic framework for analyzing foreign policy decision making. International Studies Review, 8 (3), 537-544.

Lieberman, R.C. (2002). Ideas, institutions, and political order: Explaining political change. The American Political Science Review, 96 (4), 697-712.

Maggiotto, M.A. and Wittkopf, E.R. (1981). American public attitudes toward foreign policy, International Studies Quarterly 25 (4), 601-31.

Mahoney, J. (2000). Path dependence in historical sociology. Theory and Society, 29 (4), $507-548$.

Mayer, G. (2004). Union membership trends in the United States. Congressional Research Service. Retrieved from:

https://digitalcommons.ilr.cornell.edu/cgi/viewcontent.cgi?article=1176\&context=key_workp lace

Miles, M.W. (1980). The Odyssey of the American Right. Oxford: Oxford University Press.

Miller, P.D. (2018). Conservative internationalism out of power. Orbis, 62 (1), 105-115.

Mudde, C. (2004). The populist zeitgeist. Government and Opposition, 39 (4), 541 - 563. 
Mullins, B. \& Leary, A. (2019, May 3). Washington's biggest lobbyist gets shut out. The Wall Street Journal, pp. A1 and A9.

NBC/Wall Street Journal (2018, October 14-17). Survey. Retrieved from: http://media1.snbcnews.com/i/today/z_creative/181259\%20NBCWSJ\%20October\%20Poll\%20Final.pdf.

Nichols, C. and Myers, A.S. (2010). Exploiting the opportunity for reconstructive leadership: Presidential responses to enervated political regimes. American Politics Research 38 (5), 806-841.

Nincic, M. and Datta, M.N. (2007). Of paradise, power and pachyderms. Political Science Quarterly, 122 (2), 239-56.

O'Brien, K. and Sygna, L. (2013, June). Responding to climate change: the three spheres of transformation. In Proceedings of Transformation in a Changing Climate (16-23). Oslo: University of Oslo. Retrieved from:

https://www.sv.uio.no/iss/english/research/projects/adaptation/publications/1-responding-toclimate-change---three-spheres-of-transformation_obrien-and-sygna_webversion_final.pdf O’Hanlon, M.E. (2919). The Senkaku Paradox: Risking Great Power War over Small Stakes, Washington DC: Brookings Institution Press.

Orren, K. and Skowronek, S. (2004). The Search for American Political Development.

Cambridge: Cambridge University Press.

Osnos, E. (2018, May 14). Trump vs the 'deep state'. The New Yorker. Retrieved from: https://www.newyorker.com/magazine/2018/05/21/trump-vs-the-deep-state. 
Ozkececi-Tanner, B. (2006). Reviewing the literature on sequential/dynamic foreign policy decision making. International Studies Review, 8 (3), 545-554.

Page, B.I. and Shapiro, R.Y. (1992). The Rational Public: Fifty Years of Trends in Americans Policy Preferences. Chicago: University of Chicago Press.

Parameswaran, P. (2017, October, 27). Trump's Indo-Pacific strategy challenge. The Diplomat. Retrieved from: https://thediplomat.com/2017/10/trumps-indo-pacific-strategychallenge/.

Pastor, R. (1980). Congress and the Politics of U.S. Foreign Economic Policy: 1929- 1976. Berkeley: University of California Press.

Pelling, M. (2011). Adaptation to Climate Change. From Resilience to Transformation, Oxford: Routledge.

Pence, M. (2018, October 4). Remarks by Vice President Pence on the administration's policy toward China. Hudson Institute. Retrieved from:

https://www.whitehouse.gov/briefings-statements/remarks-vice-president-penceadministrations-policy-toward-china/

Pesca, M. (2018, April 24). The Trump administration is decimating the State Department. Slate.com. Retrieved from: https://slate.com/news-and-politics/2018/04/ronan-farrow-on-thedemise-of-the-state-department-president-trump-and-the-power-of-mike-pompeo.html.

Pew Research Center (2018, November 29). Conflicting partisan priorities for U.S. foreign policy. Washington DC. Retrieved from https://www.peoplepress.org/2018/11/29/conflicting-partisan-priorities-for-u-s-foreign-policy/ 
Pfiffner, J.P. (2018). The contemporary presidency: Organizing the Trump presidency. Presidential Studies Quarterly, 48 (1), 153-67.

Pierson, P. and Skocpol, T. (2007). American politics in the long run. In P. Pierson and T. Skocpol (eds.) The Transformation of American Politics (pp. 3-16). Princeton: Princeton University Press.

Phillip, A. and Nakamura, D. (2017, May 22). utocrats hear a clear message during Trump trip: U.S. will not 'lecture' on human rights. The Washington Post. Retrieved from: https://www.washingtonpost.com/politics/autocrats-hear-a-clear-message-during-trump-tripus-will-not-lecture-on-human-rights/2017/05/22/1c7328b4-3f0c-11e7-8c2544d09ff5a4a8_story.html?utm_term=.3dd0f3b928a0.

Polanyi, K. (2001, orig. 1944). The Great Transformation: The Political and Economic Origins of our Time, Boston: Beacon Press.

Porter, P. (2018). Why America's' grand strategy has not changed: Power, habit and the U.S. foreign policy establishment. International Security, 42 (4), 9-46.

Quinn, A. and Kitchen, N. (2019). Understanding American power: Conceptual clarity, strategic priorities, and the decline debate. Global Policy, 10 (1), 5-18.

Risse-Kappen, T. (1994). Ideas do not float freely: transnational coalitions, domestic structures, and the end of the cold war. International Organization, 48 (2), 185-214. 
Rogin, J. (2017, February 4). Inside the White House-cabinet battle over Trump's immigration order. Washington Post. Retrieved from:

https://www.washingtonpost.com/news/josh-rogin/wp/2017/02/04/the-white-house-cabinetbattle-over-trumps-immigration-ban/

Rohde, D. (2019, January 31). Is Trump trying to bully America's intelligence agencies into silence? The New Yorker. Retrieved from: https://www.newyorker.com/news/dailycomment/is-trump-trying-to-bully-americas-intelligence-agencies-into-silence.

Rosati, J.A. (1994). Cycles in foreign policy restructuring: The politics of continuity and change in US foreign policy. In J.A. Rosati, J.D.Hagan \& M.W. Sampson (eds) Foreign Policy Restructuring: How Governments Respond to Global Change (pp. 221-61). Columbia: University of South Carolina Press.

Rosati, J.A. Hagan, J.D. \& Sampson, M.W. (eds) (1994). Foreign Policy Restructuring: How Governments Respond to Global Change. Columbia: University of South Carolina Press.

Ruggie, J.G. (1996). Winning the Peace: America and World Order in the New Era. New York: Columbia University Press.

Runde, D.F. and Bandura, R. (2018, October 12). The BUILD Act has passed: What's next? Center for Strategic and International Studies. Retrieved from: https://www.csis.org/analysis/build-act-has-passed-whats-next 
Rynhold, J. (2007). Cultural shift and foreign policy change: Israel and the making of the Oslo accords. Cooperation and Conflict, 42 (4), 419-440.

Seligman, L. and Gramer, R. (2019, March 12). At Trump's Pentagon, empty offices are the new normal. ForeignPolicy.com. Retrieved from: https://foreignpolicy.com/2019/03/12/attrumps-pentagon-empty-offices-are-the-new-normal-department-of-defense-mattisresignation-vacancies-trump-administration-shanahan/.

Sharp, T. (2018, April 27). President Trump's 2018 defense budget: Where does it really rank, historically? Modern War Institute. Retrieved from: https://mwi.usma.edu/presidenttrumps-2019-defense-budget-really-rank-historically/..

Sipher, J. and Haas, B. (2019, January 31). Trump's moves against the intelligence community are hurting US national security. Just Security. Retrieved from: https://www.justsecurity.org/62439/trumps-moves-intelligence-community-cripplingu-s-national-security/.

Skelley, G. (2017, June 1). Just How Many Obama 2012-Trump 2016 Voters Were There? Rasmussen Reports. Retrieved from:

http://www.rasmussenreports.com/public_content/political_commentary/commentary_by_ge offrey_skelley/just_how_many_obama_2012_trump_2016_voters_were_there

Skowronek, S. (2011). Presidential Leadership in Political Time: Reprise and Reappraisal, Second Edition, Lawrence: University Press of Kansas 
Slick, S. (2018, December 17). Restoring U.S. Intelligence after the Trump presidency. Lawfare.com. Retrieved from: https://www.lawfareblog.com/restoring-us-intelligence-aftertrump-presidency.

Smeltz, D., Daalder, I., Friedhoff, K., Kafura, C., \& Wojtowicz, L. (2018). America engaged: American public opinion and US foreign policy. Chicago Council Survey. Retrieved from: https://www.thechicagocouncil.org/sites/default/files/report_ccs18_americaengaged_181002.pdf

Smith, S. (2016, May 11). Trump supporters differ from other GOP voters on foreign policy, immigration issues. Pew Research Center. Retrieved from: https://www.pewresearch.org/fact-tank/2016/05/11/trump-supporters-differ-from-other-gopvoters-on-foreign-policy-immigration-issues/

Stevenson, C.A. (2008). The story behind the National Security Act of 1947. Military Review, 88 (3), 13-20.

Stokes, D. (2018). Trump, American hegemony and the future of the liberal international order, International Affairs 94 (1), 133-50.

Tarrance, V.L. (2019). Public opinion and U.S. engagement with the world. Gallup.com Retrieved from: https://news.gallup.com/opinion/polling-matters/248588/public-opinionengagement-world.aspx

Thompson, W.A.P. (2015). Transformative presidents: A review of definitions focused on the Reagan presidency. International Relations and Diplomacy, 3 (7), 487-925. 
Trubowitz, P. (1998). Defining the National Interest: Conflict and Change in American Foreign Policy. Chicago: University of Chicago Press.

Trump, D. (2017, January 20). Remarks of President Donald J Trump, as prepared for delivery: Inaugural address. Retrieved from: https://www.whitehouse.gov/briefingsstatements/the-inaugural-address/.

Tyson, A. \& Maniam, S. (2016, November 9). Behind Trump's victory: Divisions by race, gender, education. Pew Research Center, Retrieved from: https://www.pewresearch.org/facttank/2016/11/09/behind-trumps-victory-divisions-by-race-gender-education/.

Volgy, T.J. \& Schwarz, J.E. (1994). Foreign policy restructuring and the myriad webs of restraint. In J.A. Rosati, J.D. Hagan \& M.W. Sampson (eds) Foreign Policy Restructuring: How Governments Respond to Global Change (pp. 22-39). Columbia: University of South Carolina Press.

Walsh, J. (2006). Policy failure and policy change: British security policy after the Cold War. Comparative Political Studies, 39 (4), 490-518.

Welch, D.A. (2005). Painful Choices: A Theory of Foreign Policy Change. Princeton: Princeton University Press.

The White House, (2018, October 4). Remarks by Vice President Pence on the Administration's Policy toward China. Retrieved from: https://www.whitehouse.gov/briefings-statements/remarks-vice-president-penceadministrations-policy-toward-china/ 
Wilson, C.A. (2000). Policy regimes and policy change. Journal of Public Policy, 20 (3), 247-274.

Winter, J., Gramer, R., \& De Luce, D. (2017, July 21). Trump assigns White House team to target Iran nuclear deal, sidelining State Department. Foreign Policy.com. Retrieved from: https://foreignpolicy.com/2017/07/21/trump-assigns-white-house-team-to-target-iran-nucleardeal-sidelining-state-department/.

Wojczewski, T. (2019). Trump, populism, and American foreign policy. Foreign Policy Analysis, Advance online publication. doi.org/10.1093/fpa/orz021

\footnotetext{
1 The debate over Trump and the degree of change in US foreign policy is very similar in this regard to the debate over hegemonic decline, which is characterised by fundamental conceptual differences over the meaning of power itself which in turn lead to widely differing interpretations of the same empirical phenomena (Quinn and Kitchen, 2018).
}

2 The claim that business factions were tied to the New Deal has however been subject to challenge (Domhoff, 1990: 232-5).

\begin{abstract}
${ }^{3}$ A shared paradigm does not preclude profound disagreements about policy instruments and the ordering of goals although it sets boundaries on those disagreements. There were for example significant differences within liberal internationalism about the character of cooperation with allied nations and the responsibility and capacity of the US to take action unilaterally (Holsti and Rosenau, 1990).
\end{abstract}
${ }^{4}$ Different terms have been used to describe this tendency, including 'hard-liners', militant internationalism and conservative internationalism (Holsti and Rosenau, 1990). We prefer the latter, since 'hard-liners' is somewhat generic.

\footnotetext{
${ }^{5}$ See the article by Holland and Fermor in this special issue for a more extensive discussion of this question.
} 
${ }^{6}$ There have been other continuities. The US's relationship with Israel was bolstered by the relocation of the embassy to Jerusalem and the publication of the January 2020 peace plan for the Palestinian territories. There were also echoes of the 'coalition of the willing' assembled for the 2003 Iraq war in the administration's commitment to bring together an array of countries, including South Korea and Japan, to provide maritime security in the region around the Strait of Hormuz (Johnson, 2020).

${ }^{7}$ The argument that the US should make more extensive and creative use of sanctions had institutional implications insofar as it would bring the Treasury more directly into the making of security and foreign policy. 